\title{
An Overview on the Freedom of Religion in Albania
}

\author{
Evalda Jera, PhD Cand.
}

evaldajera@yahoo.com

Doi:10.5901/mjss.2015.v6n2s5p255

\begin{abstract}
If we take a look at the historical course of the independent Albanian state, which is established in 1912, we found Albania divided into two major religions, Christians and Muslims. After the declaration of independence of Albania in 1912, the clergy of the three faiths ranged between political, social and national movement wars arm, to do the best for the country. Albania throughout its history has been an example of how people of different religions have been able to correctly solve the trust relationship with the nation, the nation above all. Even after the declaration of the Republic of Albanian in 1925, again it was sanctioned the state with the principles of secularism and freedom of religion and conscience, principles which will also be reaffirmed in the status of the Albanian Kingdom of 1929. Things changed though with the coming of communism into power. Communists held a criminal attitude towards the religion. We can say that in 1945 the government decided to persecute the religious belief. For years Albanian communist regime deprived the freedom of conscience and religion, violating one of the fundamental rights and human freedoms. The communist regime's atrocities during his 50 years of worship destroyed indiscriminately facilities such as those of Muslim, Catholic or Orthodox believes, being justified as an atheist youth movement. Atheism in Albania concluded with the advent of democracy on 4 November 1990, after a long collapse of atheist rules. Albanian law already protects the freedom of conscience and religion as a fundamental constitutional right.
\end{abstract}

Keywords: religion, freedom of conscience, law, atheism

\section{Introduction}

We can say that freedom of religion and conscience is one of the oldest human rights recognized internationally. If we look back through a glance at ancient times, in their infancy lllyrians were pagan who had built their trust over symbols. So Albania can be considered a religious center in the Mediterranean, a place where historically Latin traditions coexisted. Later on it was Christianity that gave a stronger identity to Albanian people. So, before submission to the Albanian lands by Ottoman Empire during the fifteenth and the sixteenth centuries, Albanians had embraced Christianity ${ }^{1}$. With the Ottoman conquest of most Muslim Albanians returned for a variety of reasons ranging from the grip of fear to influence those who gain privileges. George Kastrioti, Albanian national hero Skanderbeg, is a symbol of civilization and Christian-Islamic tolerance. Skanderbeg appreciated more the unity of the nation and the unity of the Albanians. Albanian interests became primary when he came to protect the homeland. Skanderbeg found in people the strength to challenge in the name of freedom everywhere, he found it in the spiritual unity of religious and cultural identity of the Albanian people. Whole Europe, which is the cradle of ancient civilization, has listed Skanderbeg as the most prominent figures of this continent as a symbol of Christian-Islamic civilization. The Albanian Catholic Church, unlikely from the counterparts in Europe, was characterized by an independence of its components as the result of the internal situation and powerful patriotic efforts, which made the clergy in our country to give priority to national principles. It is to be noted that same as in the XV and XVI century, in contrast to the eastern rite, the Catholic Church encouraged the use of Albanian language in 1861, which testifies the high sense of patriotic Albanian clergy. The Albanian Independency of 1912 found the country divided into two major religions. Albania throughout its history has been an example of how people of faith have been able to correctly solve the trust relationship with the nation. The First World War period and then during 1918-1920, showed that the existence of religions became vital for maintaining independence and strengthening the state, the nation above all, a reality that was evaluated by the external international opinion. Thus, in the following years the religion was institutionalized more and more in the service of faith and nation. The period of Constitutional Acts of Independence confirmed the separation of religion from the state. These were placed in the Organic Statute of Albania who was a "card donated" by the European Great Powers of the time, and later in the "Statute of the Albanian state" of 1922, which sanctioned that the state had no official religion, was guaranteed the respect of religious freedom and the right to change

${ }^{1}$ Myftiu, G;Besimet Fetare; Trashigimin Kulturore Shqiptare http://www. shqiperia. com/tr/besimet_fetare. php 
religion. Even after the declaration of the Republic of Albania in 1925 was again sanctioned, it states the principles of secularism and freedom of conscience and religion, principles which will also reaffirmed the status of the Albanian Kingdom of 1929. The period between 1920-1939 the policy of state aimed to place strict national principles for the activities of religious institutions, but also a state control over religious communities. This policy was developed in order to achieve coexistence and understanding of the three religious communities operating in Albania, and to turn them into supporters of the Ahmet Zogu's regime ${ }^{2}$. So the Albanian politics was linked with the intention to establish a unity of the Albanian nation, to avoid religious disruption, which would be dangerous for the future of terrestrial integrity of the country. For this reason, Ahmet Zogu tried to separate the state from religion, to maintain peace and to understand the religious relations. Clergy were thrown totally against Italian fascism and German Nazism. This was the reason that 1933 Catholic bishop will jointly write Zogu "We are here in Albania for two thousand years, then Catholic and Catholics today, then Albanians and Albanians today and forever". Historical facts also show that in the years 1944-1990 communist ideas in the whole world and in Albania were spreading rapidly. It is clear why the communist ideology was so hostility to the religion. The fact is that with the advent of the ruling communists they held their criminal attitude towards religion. The government decided in 1945 to put the religious faith targeting mainly the Catholic Church. Persecutions and prosecutions of clergy continued, schools and Catholic monasteries were closed everywhere. Despite terrible attempt to eliminate the religious freedom, communist regime never failed to extinguish it. The Catholic and the Muslim clergy became a strong opposition to the communist regime. From 1967 until 1990 the beliefs and religious institutions were forced to cease their activities. By Decree no. 4263, dated 11. 04. 1967 it was decided that the assets of the estate of religious communities become property of the state. While the 4337 Decree, dated 13111967 placed the repeal of Decree 743 of 1949 on religious communities. So religious communities were omitted legal recognition and therefore they cannot develop any activity. Communist regime's atrocities during his 50 years of worship destroyed indiscriminately Muslim, Catholic or Orthodox facilities, being justified as atheist youth movement. Religious institutions were returned to facilities for the development of public activities and other was fully collapsed. About 217 clergy were imprisoned and ended life in prison or being shot, supported by the penal code $1977^{3}$. According to this code were condemned many former clerics but also secular. Many intellectuals, scholars by name, poets and writers, as at Shtjefën Gjeçovi, Preng Docin at George Fishta, Dom Ndre Mjedën, at Donat Kurti, etc., who had origins of the Catholic Church had suffered a deep blow. Albania was proclaimed atheist being surprised the entire world in which freedom of conscience and religion was a fundamental right. The atheism in Albania concluded with the advent of democracy, in year 1990. Thus began again establishment of churches, mosques, and a right, which was denied for tens of years. Today in the 21st century we have consolidated the systems of protection of the fundamental rights and freedoms. The rule of law is essential and distinctive feature of every society. At the core of every democracy is the government by the people for the people. The most significant feature of the rule of law is the Constitution, which is a public agreement between all individuals. Today in all democratic countries, the respect for freedoms and human rights, general principles of freedom and human rights are affirmed in the Constitution. Our Constitution has specifically stressed the principle of a society in its religious coexistence in its Preamble. The Constitution of the Republic of Albania as the fundamental law which has basic principles of organization and functioning of the state, a special place reserves the freedom of conscience and religion, realizing protection of the right of faith in some of its articles. As a fundamental right, freedom of conscience and religion occupies an important place being enshrined in several articles of the Constitution. Article 3 affirms the "religious coexistence". In Article 24 it is confirmed: Freedom of conscience and of religion is guaranteed, everyone is free to choose or change his religion or belief, and to express them individually or collectively, in public or in private life through religious education, practice or observance. Also the third paragraph of this article states that no one may be compelled or prohibited to take part in a religious community or its practices, and to make public his opinions and beliefs. In Article 24, freedom of conscience and religion is presented with its dual character. In the first place it means that everyone is free to choose not only religion, but also to change his religion or beliefs individually or collectively, in public or in private life through religious teaching practice or observance. The last paragraph of Article 24 states: "No one may be compelled or prohibited to take part in a religious community or its practices" seems to have reinforced the second aspect better. This is not only the affirmation of the right to practice the religion or religious beliefs, but also adds participation in a religious community and its practices. The right to worship is based not simply on the human right to associate and to form associations in general, which in fact is quite concerning, but sanctioned the right to participate in the life and practices of religious communities, as a personal right. It seems that freedom of conscience and religion is ranked in parallel with

\footnotetext{
${ }^{2}$ Anastas, i A; (2003) Fetë dhe Civilizimet në Mijëvjecarin e Ri-Rasti Shqipërisë;Tiranë;

${ }^{3}$ Hotova, M; (1996) Toleranca burim i hapsirës ekumenike dhe ia artit ekumenik në Ballkan; Tiranë; 
other fundamental rights such as freedom of speech and assembly ${ }^{4}$. Every citizen may freely choose his faith and to manifest religious beliefs freely. The individual in each institution and public space has the constitutionally legitimate right to respect and declare his or her religious faith without fear of discrimination. The declaration or application of religion in the above article cannot be limited in any space. Article 10 establishes the Albanian state neutrality in relation to religious communities and to report on matters of faith and conscience in general. So, a Secularism state means that the Constitution does not recognize the official religion. The Constitution of Albania creates the same opportunity for equality between religious communities. The state also recognizes the freedom of each individual to participate in a religious community and to attend its practice. This is an individual freedom. In addition, the right of freedom of religion evolves the personal right to participate in the life and practice of religious communities. Also, in the first part of the Constitutional, precisely in its Article 10, it states inter alia that: State and religious communities mutually respect the independence of one another and work together for the good of each and everyone. The relationships between the state and religious communities are regulated on the basis of agreements signed between their representatives and the Council of Ministers. Not all states are enshrined in the Basic Law of the State the right of religion or the right to choose one's religion. Article 18 is the classic article of equality, prohibits unfair discrimination on religious grounds. Also the national minorities have the right to express freely without being stopped or forced their religious affiliation, have the right to preserve and develop it by guaranteeing this right in Article 20 of the Constitution. Moreover, Article 9.2 prohibits political parties and other organizations whose programs are based on totalitarian methods that promote hatred or support races, religious, regional or ethnic due to religion or religious beliefs are unconstitutional. Inciting hatred and religious strife constitutes a criminal offense punishable by the Penal Code with a fine or imprisonment up to ten years. Also, destruction or damage of religious objects and prevention of religious ceremonies, considered as offenses, are punishable. Albanian state within its budget allocates funds from the state to come to the assistance of religious communities. So bilateral relations between the state and religious communities are regulated on the basis of relations connected between their representatives and the Council of Ministers. These agreements are ratified by the Parliament. So religious communities are independent from the state. From the standpoint of internal religious communities, they are considered as an element of the social body, equipped with its own legal personality and organizational and managerial autonomy, under the rules of general law ${ }^{5}$. As legal sources, regulating the relations of religious communities, are signed and ratified the four agreements. It ratified the agreement between the Government of Albania and the Holy See Vatican in 2005. It also ratified the Law no. 10056, dated 22. 01. 2009 "On ratification of the Agreement between the Government of the Republic of Albania and the Albanian Islamic Community. "On ratification of the Agreement between the Government of the Republic of Albania and the Albanian Orthodox Church, is another law for the regulation of bilateral relations. And Law no. 10058 dated 22. 01. 2009 "On ratification of agreements between the Government of the Republic of Albania and the World Bektashi, for regulation of bilateral relations. As it was noted above the special thing about this is that these rates are external sources of law, very similar to the international acts that become part of the internal system. This is because law in Parliament ratified the agreement between the Government and Communities. The state cannot interfere in the affairs of religious communities, but through agreements mentioned above place the independence of religious communities, implying somehow that they are considered as foreign troops to the state. Regarding the scope of these agreements can say that they guarantee the exercise of rights guaranteed by the Constitution and laws relating to freedom of conscience and religion: to recognize and guarantee respect for the rights of the religious community, institutions and its structures, as well as legal persons established by them, to freely develop their mission religious, educational and charitable. The state recognize and guarantee the integrity of the freedom of conscience and religion, institutions of worship as far as their activity does not clash with the Constitution and the laws. To ensure the freedom of the individual to choose or change religion, to manifest it individually or collectively religious institutions, or outside them, through worship, education, practices or the performance of religious rites. To ensure the freedom of the individual to not stop and neither compelled to belong to a religious community, or participate in practices, rituals and its management structures. Through this agreement, the parties commit to ensuring freedom of thought, conscience and religion. This freedom cannot be made subject to restrictions other than those provided for by law, which contains measures necessary in a democratic society, public safety, for the protection of public order, the state of health of morals. Albania has a great religious tolerance between Catholics, Muslims and Orthodox Albanians. In Albania, although there are three religions and four communities, religious conflicts haven't been noticed. While religious phenomenon has emerged that when beliefs and religions were born, one religion is tolerant of other religions ${ }^{6}$. It should be noted that religious beliefs in Albania has always

\footnotetext{
${ }^{4}$ Anastasi, A; (2003), Fetë dhe civilizimet në mijëvjecarin e ri- rasti i Shqipërisë;

${ }^{5}$ Anastasi, A(2003); Fete dhe civilizimet në mijevjecarine e ri; Rasti I Shqipërisë;

${ }^{6}$ Hetova, M; (1996) Tolerance burim i hapësirës ekumenike dhe i artit ekumenik në Ballkan; Toena;Tiranë; 
characterized a strong feeling and sincere harmony which is reflected in the relations between people with different religious beliefs, as well as between religious people and atheists. Albanians are both Christian and Muslim; they are Catholic and Orthodox, Sunni and Bektashi. In Albania there is a remarkable religious pluralism. Religions have not been and are not a source of conflict in society. If we have a look in the history of the religious communities in Albania, they have always succeeded ${ }^{7}$. This tolerance stems from the awareness of the Albanians that they belong to the same nation having a strong ethnic identity regardless of external factors affecting the determination of the various religious in Albania. Albanians have always been aware that they belong to the same nation, have never had conflict between their religious natures. Also, Enver Hoxha followed another factor that contributed to the consolidation of tolerance and intelligence cooperation between religious communities atheist policy. The spirit of good will and harmony that characterizes traditional religious communities are affected by common difficulties they have encountered in the communist past. Religious tolerance has always been present in the Albanian lands. Believers of different religions did not only respect religious holidays, but they were often also a cause for celebration regardless of which religion you belongs. Specifically, Shkodra is a concrete example of tolerance and coexistence that characterizes also the whole Albanians. We can say that in Albania you can often find two different religions within the same family or a tribe, or it's no wonder that even one person follows the rites of religious holidays for both religions whether Muslim or Catholic. Tolerance and understanding exists between communities by making Albanians proud of the relationships that exist between them. At the end we can say that religious tolerance in the Albanian national tradition is one of the main characteristics of the morality of the Albanian people. The vast majority of the Albanian people are of Islamic faith, but everyone knows that their fathers were Christian and one of them does not deny this historical fact. Albanians belong mainly to three religions, and this has contributed into that they do not dominate social life and in any period of time religion was not a state component. They have been separated from the state who respect them, except dark period of dictatorship, the communist regime of Enver Hoxha during 1945-1991 when religious tolerance was heavy tread, when Albania necessarily turned in to an atheist state. It seems that the Albanians throughout their history have been and are oriented towards Western Europe, towards its Christian culture, democracy, politics, economy and their national interest. The interest of the nation has always been primary in relation to religious matters as well said from Pashko Vasa in the nineteenth century, ..." the religion of Albanians is albanisem"8. Tolerance is in interest of every individual, every family and every state. It creates a humane atmosphere and opens the way for peace and friendship between people not only in Albania but worldwide.

\section{References}

Anastasi, A ; (2003) Fetë dhe Civilizimet në Mijëvjecarin e Ri-Rasti Shqipërisë;Tiranë;

Hotova, M; (1996) Toleranca burim i hapsirës ekumenike dhe ia artit ekumenik në Ballkan; Tiranë;

Morozzo della Rocca, R; (2003), Fetë dhe Civilizimet në mijëvjecarin e ri;; Botim i Qëndra shqiptare për të Drejtat e Njeriut; Krasniqi, M; Toleranca në traditën shqiptare; Botime te Shkencave; Prishtine;

Pan, N (2003); Fetë dhe Civilizimet në Mijëvjecarin e Ri-Rasti Shqipërisë; Tiranë

Myftiu,G;Besimet Fetare; Trashigimin Kulturore Shqiptare: http://www. shqiperia. com/tr/besimet_fetare. php

\footnotetext{
${ }^{7}$ Morozzo della Rocca, R; (2003) Fetë dhe Civilizimet në mijëvjecarin e ri; Botim i Qëndra shqiptare për të Drejtat e Njeriut;

${ }^{8}$ Krasniqi, M; Toleranca në traditën shqiptare; Botime te Shkencave; Prishtine 